\title{
LEGISLATIVE CONTROLS ON DIRECTOR AND EXECUTIVE TERMINATION PAYMENTS IN THE UK AND AUSTRALIA - LESSONS FOR SOUTH AFRICA
}

\author{
Vela Madlela \\ LLB LLM \\ Lecturer in Mercantile Law \\ University of South Africa (UNISA)
}

\section{SUMMARY}

The awarding of termination payments to departing company directors and senior executives has attracted a lot of controversy in many jurisdictions in light of the excessive nature and size of termination packages, as well as the corporate governance flaws in the process by which these payments are determined. Termination payments are frequently perceived to be rewards for failure in view of the large packages that have been paid to company executives on termination of their service contracts, often following poor financial performance and staff retrenchments. This article examines the legislative controls on termination payments in the UK under the Companies Act 2006, and in Australia under the Corporations Act 2001. It then evaluates the position in South Africa under the Companies Act 71 of 2008 in light of the approaches followed by the UK and Australia. The article concludes that the provisions of the Companies Act 71 of 2008, relating to directors' and executives' termination payments are inadequate to promote transparency, accountability and certainty. It further makes proposals for more robust regulation of directors'-and executive-termination payments under the Companies Act 71 of 2008.

\section{INTRODUCTION}

Termination payments, commonly known as "golden handshakes", are packages awarded to company directors and senior executives upon termination of their service contracts or retirement from office. They are usually contained in directors' and executives' contracts of service and provide a guarantee that they will receive a lucrative cash payment and other benefits in the event of a termination. ${ }^{1}$

The practice of awarding termination payments to departing company directors and senior executives has been a subject of increasing public and

The various types of payments or benefits that may be received under termination agreements include inter alia guaranteed annual basic salary and bonuses for a specified period of time, automatic or accelerated vesting of share-based payments and payments in lieu of notice. 
shareholder scrutiny in most jurisdictions in the post 2008-2009 global financial-crisis period. This is mainly due to the nature of termination payments, the sheer size of these payments and the serious corporate governance challenges often found in the determination of these payments. ${ }^{2}$ Termination payments are also frequently perceived to be rewards for failure in view of the large packages that are paid to company executives on termination of their service contracts, often following poor financial performance and staff retrenchments. ${ }^{3}$

The purpose of this article is to explore the approaches followed by the UK and Australian legislatures in seeking to control the glaring corporate governance deficiencies associated with termination payments, and to suggest legislative reforms for South Africa in this area of corporate law. The article first discusses the justifications for the termination payments made by companies to departing directors and senior executives. It further considers the corporate governance challenges in this area, before examining the legislative controls on termination payments in the UK under the Companies Act 2006, ${ }^{4}$ as amended, and in Australia under the Corporations Act 2001, as amended. ${ }^{5}$ The article then evaluates the position in South Africa under the Companies Act 71 of 2008, as amended, in light of the approaches of both the UK and Australia. Lastly, the article makes proposals for legislative reform in South Africa as well as some concluding remarks.

\section{THE RATIONALE FOR TERMINATION PAYMENTS}

Various reasons have been advanced for the provision of lucrative termination payments by companies to their departing executives. According to proponents of this practice, termination-payment agreements are necessitated by the need on the part of companies to attract and retain competent directors and senior executives. ${ }^{6}$ They argue that it would be difficult for a company that does not enter into these arrangements to engage competent directors and executives, particularly where such directors and executives are leaving secure employment or positions. ${ }^{7}$ In the same vein, they maintain, a company that does not enter into terminationpayment agreements risks losing its skilled directors and senior executives to competitors. ${ }^{8}$

Shields, O'Donnell and O'Brien "The Bucks Stop Here: Private Sector Executive Remuneration in Australia" A Report prepared for the Labor Council of New South Wales 2003 http://www.researchgate.net/publication/242042789 (accessed 2016-02-27) 8.

3 See, eg, The Parliament of the Commonwealth of Australia "Corporations Amendment (improving accountability on termination payments) Bill 2009 Explanatory Memorandum" (2009) https://www.comlaw.gov.au/Details/C2009B00146/Download (accessed 2016-01-20) 11-12.

Hereinafter "the UK Companies Act 2006".

Hereinafter "the Australian Corporations Act 2001".

Hood and Benge "Golden parachute agreements: reasonable compensation or disguised bribery?" 198553 UMKC LR 199 204. In this article the authors discuss the rationale for employment contracts that guarantee lucrative financial payments to company executives when their companies change control on an acquisition or merger.

Ibid.

8 Ibid. 
Notably, termination-payment arrangements are made in advance to the directors and executives. As such, they provide security to incoming company directors and executives against involuntary or early termination from employment. ${ }^{9}$ The security provided by these arrangements presumably encourages the directors and executives to take risks and actively pursue strategies that will enhance the value of the company and benefit its shareholders. ${ }^{10}$ It has also been asserted that the security provided by the termination payments may play a role in mitigating the fear of dismissal during the directors' and executives' tenure in office. ${ }^{11}$ This, it is argued, may aid in discouraging directors and executives from concealing negative information from shareholders in order to avert the possibility of removal from office, or from shirking when they feel that their removal has become likely. ${ }^{12}$ Thus, according to David Yermack, termination payments may make departure a more attractive option to under-performing executives than holding on to their positions, even in situations where the board is too weak to remove them, or where the board does not have adequate information to justify their removal. ${ }^{13}$

Another reason given for termination payments is that these lucrative payments may serve as a mechanism for damage control when directors and executives are dismissed. ${ }^{14}$ They may encourage the dismissed directors or executives to leave the company "quietly" and not to divulge the company's confidential information to competitors or compete with the company. ${ }^{15}$ Moreover, termination payments may also serve to prevent disgruntled executives from instituting costly litigation against the company. ${ }^{16}$

A further justification for termination payments is that they represent a special recognition of service ${ }^{17}$ and provide a mechanism by which the board of directors evaluates the achievements of the individual director or executive at the end of his term of office and reward him accordingly. ${ }^{18}$

\section{CORPORATE GOVERNANCE CHALLENGES ASSOCIATED WITH TERMINATION PAYMENTS}

Despite the arguments in favour of the practice of awarding termination payments to company directors and senior executives presented above, termination arrangements raise serious questions about corporate governance most of the time. There is often a lack of transparency in regard

\footnotetext{
Yermack "Golden handshakes: Separation pay for retired and dismissed CEOs" 200641 Journal of Accounting and Economics 237240.

Yermack 200641 Journal of Accounting and Economics 240-241.

Ibid.

Ibid.

Ibid.

Ibid. See also Shields, O'Donnell and O'Brien 2003 http://www.researchgate.net/publication /242042789 7.

15 Yermack 200641 Journal of Accounting and Economics 241-242; Shields, O'Donnell and O'Brien 2003 http://www.researchgate.net/publication/242042789 7.

16 Yermack 200641 Journal of Accounting and Economics 242.

17 Shields, O'Donnell and O'Brien 2003 http://www.researchgate.net/publication/242042789 7.

18 Yermack 200641 Journal of Accounting and Economics 239-240.
} 
to the basis for, and the scale of, these payments. ${ }^{19}$ Indeed, very few companies have transparent mechanisms in place for calculating termination payments. ${ }^{20}$ Termination arrangements are also frequently imbedded in most executive contracts in South Africa, while they are not disclosed in the remuneration policies put to shareholder approval. Shareholders and other stakeholders are usually informed of these lucrative payments when payments have already been made. Consequently, in some jurisdictions legislation requires advance disclosure of any termination-payment arrangement in order to mitigate potential abuse. ${ }^{21}$

In addition, there is lack of fairness and objectivity in the procedures by which termination payments are determined. In a country such as South Africa the directors' powers of management are statutorily entrenched. ${ }^{22}$ The responsibility for determining the remuneration packages of directors and senior executives (including the termination packages) ultimately rests with the board of directors. South Africa also has a unitary board structure, comprising of both executive and non-executive directors. Therefore, there is a very high potential for conflict of interests when directors have to determine the termination arrangements of fellow directors.

While it is common practice for companies to establish so-called independent remuneration committees, comprising non-executive directors to determine company directors' and executives' remuneration packages, the role of such committees is only an advisory one. The final authorization is the prerogative of the board. ${ }^{23}$ In any event, the independence and effectiveness of remuneration committees are hampered by a variety of social, economic and psychological factors, including feelings of friendship and loyalty amongst executive and non-executive directors. ${ }^{24}$ It has been

\footnotetext{
Shields, O'Donnell and O'Brien 2003 http://www.researchgate.net/publication/242042789 8. Ibid.

21 See paragraphs 4 and 5 below for a discussion of the relevant provisions of the UK Companies Act 2006 and the Australian Corporations Act 2001. See also s 951 of the Dodd-Frank Wall Street Reform and Consumer Protection Act of 2010 in the USA, which provides for a non-binding shareholder vote on any agreements or understandings that the company has with any of its named executive officers concerning any type of compensation that is based on, or otherwise relates to the acquisition, merger consolidation, sale, or other disposition of all or substantially all of the assets of the company.

22 S 66(1) of 71 of 2008

23 Davis, Geach, Mongalo Companies and other Business Structures in South Africa 3ed (2013) 142-143. See also Institute of Directors in Southern Africa Practice Notes "A guide to the application of King III: Remuneration" October $2012 \mathrm{http}: / / \mathrm{c} . y m c d n . c o m / s i t e s /$ www.iodsa.co.za/resource/collection/24CB4885-33FA-4D34-BB84-E559E336FF4E/King_II Remuneration_practice_note_April_2013.pdf (accessed 2016-01-27).

24 Yablon "Overcompensating: The Corporate Lawyer and Executive Pay" 199292 Columbia LR 1867 1873; Hill "What Reward Have Ye? Disclosure of Director and Executive Remuneration in Australia" 199614 Company and Securities LJ 232 235; Ezzamel and Watson "Market Comparison Earnings and the Bidding-Up of Executive Cash Compensation: Evidence from the United Kingdom" 199841 The Academy of Management Journal 221 222; Sykes "Overcoming Poor Value Executive Remuneration: resolving the manifest conflicts of interest" 200210 Corporate Governance: An International Review 256 257; Mongalo "Shareholder activisim in the United Kingdom highlights the failure of remuneration committees: lessons for South Africa" 2003120 SALJ 756 760-763; Bebchuk and Fried "Pay Without Performance: Overview of the Issues" in Kieff and Paredes (eds) Perspectives on Corporate Governance (2010) 115-130; Ablen "Remunerating 'Fairly and Responsibly' The 'Principles of Good Corporate Governance and Best Practice
} 
observed that the majority of boards function like a closed club, with nonexecutive directors also serving as directors of comparable companies. ${ }^{25}$ In essence, executive directors often serve on each other's boards and approve each other's remuneration packages. Accordingly, it is submitted, the determination of termination payments becomes problematic since it occurs in an inherently biased set up. It is further submitted that informed shareholder oversight regarding decisions on termination payments would serve to counterbalance the defects in the way these payments are determined. ${ }^{26}$ This clearly calls for greater transparency in termination payments.

The sheer size of termination payments raises concern, especially in light of the pay gap between senior executives and the rest of the company employees. ${ }^{27}$ This is a particularly serious concern in the South African context. ${ }^{28}$ Unreasonable pay disparities could lead to conflicts between company management and employees which, in turn, could negatively impact on the company's operations. The amounts of these exit payments should thus be sensitive to pay and employment conditions elsewhere within the company. Very large termination packages during periods of retrenchments and significant cost-cutting can also have a negative impact on a company's workforce morale.

The sheer size of termination payments also raises concerns in regard to linking pay packages to performance. ${ }^{29}$ Linking pay to performance is generally viewed as one of the ways of aligning the interests of company directors and executives with not only those of shareholders but those of other stakeholder groups as well. However, as already mentioned, termination payments are often viewed as rewards for failure, where they are awarded despite poor performance. ${ }^{30}$

It is submitted, therefore, that termination payments to company directors and executives need to be controlled through legislation in a manner that will promote transparency and accountability. This would be in line with section 7(b)(iii) of the Companies Act of 2008 which lists encouraging transparency and high standards of corporate governance among the purposes of the

Recommendations' of the ASX Corporate Governance Council" 200325 Sydney LR 555 558-560.

25 Yablon 199292 Columbia LR 1873; Hill 1996 Company and Securities Law Journal 235; Ezzamel and Watson 199841 The Academy of Management Journal 222; Sykes 200210 Corporate Governance: An International Review 257; Mongalo 2003120 SALJ 760-763; Bebchuk and Fried in Kieff and Paredes (eds) Perspectives on Corporate Governance 115-130; Ablen 200325 Sydney LR 558-560.

Ablen 200325 Sydney LR 560; Hill 1996 Company and Securities Law Journal 235.

27 Shields, O'Donnell and O'Brien 2003 http://www.researchgate.net/publication/242042789 8.

28 South Africa has been described as one of the most unequal nations in the world. See Massie, Collier and Crotty Executive salaries in South Africa: Who should have a say on pay? (2014) xxii-xxxiii and 27-28. See also Inchauste, Lustig, Maskekwa, Purfield and Woolard "Fiscal policy and redistribution in an unequal society: the case of South Africa" $2014 \mathrm{http} / / / \mathrm{www}$.worldbank.org/en/country/southafrica/publication/south-africa-economic-up date-fiscal-policy-redistribution-unequal-society (accessed 2015-08-28); Oxfam "Even it up: time to end extreme inequality" $2015 \mathrm{https} / /$ www.oxfam.org/sites/www.oxfam.org/files/file attachments/cr-even-it-up-extreme-inequality-291014-summ-en.pdf (accessed 2015-08-28). Shields, O'Donnell and O'Brien 2003 http://www.researchgate.net/publication/242042789 8.

30 Ibid. 
Act. ${ }^{31}$ The legislative controls should in addition serve to promote certainty in determining the types of payments or benefits considered to be termination payments.

\section{THE UK}

The provisions on payments for loss of office in relation to UK-registered companies are contained in sections 115-222 of the UK Companies Act 2006. Additional restrictions in relation to quoted companies ${ }^{32}$ are provided for in sections 420-422 of the UK Companies Act 2006, sections 79-82 of the Enterprise and Regulatory Reform Act 2013 as well as The Large and Medium-sized Companies and Groups (Accounts and Reports) (Amendment) Regulations 2013. ${ }^{33}$

\section{Meaning of payment for loss of office}

Section 215 of the UK Companies Act 2006 defines "payment for loss of office" to mean a payment made to a director or past director of a company -

"(a) by way of compensation for loss of office as director of the company,

(b) by way of compensation for loss, while director of the company or in connection with his ceasing to be a director of it, of -

(i) any other office or employment in connection with the management of the affairs of the company, or

(ii) any office (as director or otherwise) or employment in connection with the management of the affairs of any subsidiary undertaking of the company,

(c) as consideration for or in connection with his retirement from his office as director of the company, or

(d) as consideration for or in connection with his retirement, while director of the company or in connection with his ceasing to be a director of it, from -

(i) any other office or employment in connection with the management of the affairs of the company, or

(ii) any office (as director or otherwise) or employment in connection with the management of the affairs of any subsidiary undertaking of the company.

Section 215(2) expressly states that the references to "compensation" and "consideration" include benefits otherwise than in cash and references to "payment" have a corresponding meaning. The comprehensive definition of "payment for loss of office" above also applies to the new Chapter 4A of Part

31 See also s 7(i) and (j) of 71 of 2008 which provide that the purposes of this Act are to inter alia balance the rights and obligations of shareholders and directors within companies and to encourage the efficient and responsible management of companies.

32 A "quoted company" is defined in s 385(2) of the UK Companies Act 2006 to mean a company whose equity share capital has been included in the Official List in accordance with Part 6 of the Financial Services and Markets Act 2000, or is officially listed in a European Economic Area State, or is admitted to dealing on either the New York Stock Exchange or Nasdaq.

33 Hereinafter "the 2013 Regulations".

34 This section is contained in Chapter 4 of Part 10 which deals with transactions with directors requiring approval of members. 
10 which deals with the directors of quoted companies. ${ }^{35}$ Notably, the term "remuneration payment", as defined in section $226 \mathrm{~A}(1)$, specifically excludes a "payment for loss of office".

\section{Restrictions on payments for loss of office for UK- registered companies}

\section{Shareholder approval of payments for loss of office}

Sections 217, 218 and 219 of the UK Companies Act 2006 require shareholder approval for payments for loss of office, including those made in connection with transfer of the undertaking, property or shares of the company. ${ }^{37}$ This requirement is applicable to a UK-registered company that is not a wholly-owned subsidiary of another body corporate (hereafter referred to as a "UK-registered company"). ${ }^{38}$

Requiring shareholder approval clearly helps to limit the board's discretion over payments made in return for loss of office. It also promotes transparency and accountability within company boards. It enables shareholders to vote against termination packages that are considered to be unreasonable.

Section 115(3) of the UK Companies Act 2006 specifically provides that a payment to a person connected with a director or to any person at the direction of, or for the benefit of, a director or a person connected with him, is considered as a payment to the director. Accordingly, payments to all such persons require the shareholders' approval. The expression "payment by a person" also includes payments made by another person at the direction of, or on behalf of, the first person. ${ }^{39}$ This is intended to prevent circumvention of the requirement that payments for loss of office receive the approval of shareholders by making the payment through connected persons.

The UK Companies Act 2006 provides for exceptions to the requirement of shareholder approval of payments for loss of office. In terms of sections 220 (1) shareholder approval is not required for a payment made in good faith in the following circumstances:

35 S 226A(1) of the UK Companies Act 2006, as inserted by s 80 of the Enterprise and Regulatory Reform Act 2013.

$36 \mathrm{~S} 226 \mathrm{~A}(1)$ of the UK Companies Act 2006, as inserted by $\mathrm{s} 80$ of the Enterprise and Regulatory Reform Act 2013.

37 Notably, s 217(2) further prohibits a subsidiary from making a payment for loss of office to a director of its holding company, unless the payment has been approved by a resolution of the shareholders of each of the companies. S 218(1) prohibits the making of a payment for loss of office by any person to a director of a company in connection with transfer of the undertaking or property of the company, unless the payment has been approved by a resolution of the shareholders of the company. Where the payment is in connection with the transfer of the undertaking or property of a subsidiary of the company, the payment must be approved by a resolution of the shareholders of each of the companies. In terms of $s 219(1)$ a payment for loss of office by any person to a director of the company in connection with share transfer in the company or its subsidiary, resulting from a takeover bid, also requires approval by the shareholders.

38 S 217(4), 218(4) and 219(6) of the UK Companies Act 2006.

39 S 115(4). 
- in discharge of an existing legal obligation;

- by way of damages for breach of such an obligation;

- by way of settlement or compromise of any claim arising in connection with the termination of a person's office or employment, or

- by way of pension in respect of past services.

In addition, the exception applies where the payment, including other relevant payments, does not exceed $£ 200 .{ }^{40}$

In order to promote transparency and meaningful shareholder participation, sections 217,218 and 219 provide that a resolution approving a payment for loss of office must not be passed unless a memorandum setting out particulars of the payment, including its amount, is made available to the shareholders of the company.

\section{Consequences for contravention of the provisions}

In terms of section 222(1)(a) if a company makes a payment for loss of office without shareholder approval as required by section 217 , the payment is held by the recipient on trust for the company making the payment. Moreover, a director who authorized the payment is jointly and severally liable to indemnify the company for any loss resulting from the payment. ${ }^{41}$ In the event that the contravening payment for loss of office is made in connection with the transfer of the whole or any part of the undertaking or property of the company or its subsidiary (section 218), it is held by the recipient in trust for the company whose undertaking or property is transferred or is proposed to be transferred. ${ }^{42}$ If the contravening payment is made in connection with a share transfer resulting from a takeover bid, it is held by the recipient in trust for persons who have sold their shares, based on the offer. ${ }^{43}$ All the expenses incurred by the recipient in distributing that sum will be borne by him and not deducted from that sum. ${ }^{44}$

The civil penalties provided, including the joint and several liability of directors, would strengthen compliance with the requirement for shareholder approval of payments for loss of office. The requirement that the recipient of a retirement benefit that has been given without shareholder approval must hold such benefit on trust, ensures the accountability of the recipient.

\footnotetext{
$S 221(1)$.

$\mathrm{S} 222(1)(\mathrm{b})$

$S$ 222(2). This would also be the consequence where a payment is in contravention of ss 217 and 218. See s 222(4).

$43 \mathrm{~S} 222(3)(\mathrm{a})$. See also s 222(5) which provides that if a payment is in contravention of ss 217 and 219, then $s$ 222(3) applies rather than subsection (1), unless the court orders otherwise.

44 S 222(3)(b).
} 


\section{Additional restrictions on payments for loss of office for quoted companies}

\section{Disclosure of payment for loss of office arrangements}

In addition to the requirements discussed above, the 2013 Regulations require each quoted company to disclose in the directors' remuneration policy ${ }^{45}$ information relating to all directors' service contracts, ${ }^{46}$ and the company's policy on payment for loss of office. ${ }^{47}$ Should the directors' service contracts not be available for inspection at the company's registered office, the details of where these contracts are kept must be provided. ${ }^{48}$ Further, if the contracts are available on a website, a link to that website must be given. ${ }^{49}$ The above requirements apply equally to the terms of letters of appointment of directors. ${ }^{50}$ This helps to bring transparency into termination arrangements found in directors' service contracts and letters of appointment.

Furthermore, the directors' remuneration policy must set out the company's approach to the determination of payments for loss of office. ${ }^{51}$ This must include an indication of how each component of the payment will be calculated, and an explanation of whether the director's performance during the period of service is relevant to any exercise of discretion. ${ }^{52}$

It is submitted that these requirements help to focus the attention of company boards on termination arrangements. They compel quoted companies to devise defined mechanisms for calculating payments to departing directors for loss of office. They also help to give company stakeholders insight into the termination payments awaiting the directors.

\section{Disclosure of payment for loss of office in the annual remuneration report}

In terms of regulation 16 of the 2013 Regulations, the annual directors' remuneration report for each quoted company must disclose payments for loss of office for each person who has served as a director of the company at any time during the financial year or any previous year. It must set out the total amount of any payment for loss of office, broken down into each component comprised in that payment and the value of each component. ${ }^{53}$

\footnotetext{
45 The directors' remuneration policy is defined in s 226A(1) of the UK Companies Act 2006 (inserted by s 80 of the Enterprise and Regulatory Reform Act 2013) to mean the policy of a quoted company with respect to the making of remuneration payments and payments for loss of office.

46 Regulations $30-32$ of the 2013 Regulations.

47 Regulations 36-37.

48 Regulation 31.

49 Ibid.

Regulation 32.

Regulation 37.

Ibid.

Regulation 16(a).
} 
An explanation of how each component was calculated must be provided. ${ }^{54}$ Where any discretion was exercised in respect of the payment, an explanation of how such discretion was exercised must be given. ${ }^{55}$ These disclosure requirements provide shareholders and other company stakeholders with insight on how the total termination package is comprised, as well as how it has been calculated.

\section{Shareholder control over payments for loss of office}

Shareholders of quoted companies may exercise control over termination payments in a number of ways, including through expressing their views on the formulation of the directors' remuneration policy and voting on the resolutions to approve the directors' remuneration policy. ${ }^{56}$ Shareholders are, therefore, able to engage with company boards on, amongst other things, the termination-payment provisions proposed to be included in the directors' remuneration policy.

Section 439 of the UK Companies Act 2006 further gives shareholders of a quoted company an annual advisory vote on a resolution to approve the annual directors' remuneration report at an accounts meeting. If the resolution to approve the annual directors' remuneration report is not passed the company must put the directors' remuneration policy to a binding shareholder vote the following year. ${ }^{57}$ This gives teeth to the advisory vote and compels companies to take shareholder concerns on the aspects of the annual directors' remuneration report relating to, amongst others, termination payments, more seriously.

The Enterprise and Regulatory Reform Act 2013 introduced further restrictions on directors' termination payments under the new Chapter 4A of the UK Companies Act $2006 .{ }^{58}$ According to these restrictions, any payment for loss of office that is made to a person who is, or has been, a director of a quoted company, must be consistent with the approved remuneration policy. ${ }^{59}$ Alternatively, a payment for loss of office which is not consistent with the approved remuneration policy, must be approved by a resolution of the shareholders of the company as required by section $226 \mathrm{C}$. It is,

54 Regulation 16(b).

55 Regulation 16(d).

56 In terms of s 439A read with s 421(2A) of the UK Companies Act 2006 the directors' remuneration policy must be approved by a binding ordinary resolution of the shareholders every three years (or sooner if the company wishes to make any changes to the remuneration policy). See also regulation 40 of the 2013 Regulations which provides that the directors' remuneration policy must contain a statement of whether, and if so, how, any views expressed to the company by shareholders (whether at a general meeting or otherwise) were taken into account in the formulation of the directors' remuneration policy.

57 S 439A(2) of the UK Companies Act 2006 as inserted by s 79 Enterprise and Regulatory Reform Act 2013.

58 Ch 4A of the UK Companies Act 2006 was inserted by s 80 of the Enterprise and Regulatory Reform Act 2013. This Chapter, according to s 226F(1) of the UK Companies Act 2006, does not affect the requirements for shareholder approval which apply in relation to the company under Chapter 4 (i.e. restrictions on payments for loss of office for UKregistered companies).

59 S 226C(1)(a) of the UK Companies Act 2006. In terms of s 226(2) the approved directors' remuneration policy is the most recent remuneration policy to have been approved by a resolution passed by the shareholders of the company in general meeting. 
therefore, imperative for quoted companies to adhere to the terminationpayment arrangements, as disclosed in the company's approved remuneration policy.

Notably, the restrictions on directors' termination payments apply not only to payments made by quoted companies, but also to payments for loss of office made by any person to a person who is, has been or is to be a director of a quoted company. These include payments made to a person connected with, or at the direction of, or for the benefit of the said director of a quoted company. ${ }^{60}$ Thus, the restrictions imposed on payments to directors for loss of office cannot be circumvented by making such payments through other connected persons.

Section 226D(1) of the UK Companies Act 2006 provides inter alia that a resolution, approving a payment for loss of office, must not be passed unless a memorandum setting out the particulars of the payment, including its amount, has been disclosed to shareholders. In terms of section 226(D)(2) the memorandum must explain the ways in which the payment is inconsistent with the company's approved remuneration policy. These requirements are aimed at further enhancing transparency in termination payments.

\section{Consequences of contravention of the provisions by quoted companies}

The UK Companies Act 2006 provides for severe criminal and civil consequences in the event that a quoted company fails to comply with the provisions on termination payments. Some of these apply to remuneration matters generally, whilst others apply specifically to termination payments. For instance, failure to comply with the requirement to prepare a directors' remuneration report for each financial year constitutes an offence. ${ }^{61}$ Further, directors may be held criminally liable if a directors' remuneration report that does not comply with the requirements of the UK Companies Act 2006 is approved. ${ }^{62}$ These criminal consequences would apply where a directors' remuneration policy or the annual directors' remuneration report fails to comply with the provisions on termination payments discussed above. A person guilty of the offence is liable on conviction on indictment, to a fine

${ }^{60} \mathrm{~S} 226 \mathrm{~A}(7)$ of the UK Companies Act 2006. In terms of $\mathrm{s} 226 \mathrm{~A}(7)(8)$, s 252 of the UK Companies Act applies for the purposes of determining whether a person is connected with a person who has been, or is to be, a director of a company as it applies for the purposes of determining whether a person is connected with a director. Connected persons include inter alia: members of the director's family; a body corporate with which the director is connected as defined in s 254; a person acting in his capacity as a trustee of a trust, the beneficiaries of which include the director, or a person who is connected with him; a person acting in his capacity as partner of the director, or of a person who is connected with that director; a firm in which the director is a partner; a firm in which a partner is a person who is connected with the director; a firm in which a partner is a firm in which the director is a partner, or in which there is a partner who is connected with the director.

S 420(2) of the UK Companies Act 2006.

62 The offence is committed by every person who was a director of the company immediately before the end of the period for filing accounts and reports for the financial year in question, and failed to take all reasonable steps for securing compliance with that requirement. See s 420(2)(a) and (b) of the UK Companies Act 2006. 
and on summary conviction, to a fine not exceeding the statutory maximum. ${ }^{63}$

In addition, section 226E of the UK Companies Act 2006, provides for civil consequences where a payment for loss of office is made without shareholder approval as required by section 226C. In terms of section $226 \mathrm{E}(1)$ an obligation, however arising, to make such payment which would be in contravention of section $226 \mathrm{C}$, has no effect. If a payment for loss of office is made in contravention of section $226 \mathrm{C}$, it is held by the recipient on trust for the company or the person making the payment. ${ }^{64}$ Where such payment is made by a company, the directors who authorized the payment are jointly and severally liable to indemnify the company for any loss resulting from the payment. 65

The harsh penalties discussed above would compel company boards to carefully consider the statutory requirements on termination payments that must be addressed in the remuneration policy and in the annual directors' remuneration report. They would ensure that the boards comply with the provisions in the directors' remuneration policy. The strict penalties would also help to strengthen transparency and shareholder control over termination payments.

\section{AUSTRALIA}

In Australia, termination payments to company directors and senior executives are regulated by the Corporations Act 2001 and the Corporations Regulations 2001. Division 2 of Part 2D.2 of the Australian Corporations Act 2001 contains restrictions on benefits given in connection with retirement from an office or position if a person has held a managerial or executive office. Section 200AA specifies when a person holds a managerial or executive office in the company. In the case of listed companies, a person holds a managerial or executive office in the company during a financial year if the person's details were included in the directors' report for that previous financial year for the company in accordance with section $300 \mathrm{~A}(1)(\mathrm{c}){ }^{66}$ In

63 S 420(3)(a) and (b) of the UK Companies Act 2006. See also s 440 which provides that failure to give the requisite notice of the resolution for approval of director's remuneration report constitutes an offence by every officer of the company who is in default.

$64 \mathrm{~S} 226 \mathrm{E}(2)(\mathrm{a})$. However, this does not apply to a situation where the payment for loss of office is made to a director of a quoted company in connection with the transfer of the whole or any part of the undertaking or property of the company or its subsidiary. In such a situation the payment is held by the recipient on trust for the company whose undertaking or property is being transferred (or is proposed to be transferred). See s 226E(3). Furthermore, if the payment for loss of office is made (in contravention of section 226C) in connection with a transfer of shares in the company, or in its subsidiary resulting from a takeover bid, the payment is held by the recipient on trust for persons who have sold their shares as a result of the offer. The expenses incurred by the recipient in distributing that sum amongst those persons will be borne by the recipient and not retained out of that sum. See $s$ $226 \mathrm{E}(4)$.

$65 \mathrm{~S} 226 \mathrm{E}(2)(\mathrm{b})$. However, if the director shows that he has acted honestly and reasonably, and the court considers that, having regard to all the circumstances of the case, he ought to be relieved of liability, the court may relieve the director, either wholly or in part, from liability on such terms as the court thinks fit. See section $226 \mathrm{E}(5)$.

66 S 200AA(1) of the Australian Corporations Act 2001. In terms of s 300A(1)(c) details must be given in the directors' report for each person who is a member of the key management 
the case of any other body corporate, a person holds a managerial or executive office if the person is a director of the body corporate, or holds any other office or position in connection with the management of the body corporate's affairs that is held by a person who also holds an office of director of the body corporate or a related body corporate. ${ }^{67}$ Thus the provisions apply somewhat differently to listed companies and all other companies.

Nevertheless, the ambit of the restrictions relating to retirement benefits, as defined, under the Australian Corporations Act 2001, extends to cover directors, executives and key-management personnel of the company. ${ }^{68}$ This is in contrast to the UK where the requirements on payments for loss of office only apply to company directors.

The restrictions also apply to all companies incorporated under the Australian Corporations Act 2001. This is also the case under the UK Companies Act 2006 where, as discussed above, the restrictions on payments for loss of office apply to all corporate entities which are UKregistered companies.

\section{Meaning of "retirement benefit"}

It is essential to specify the kinds of payments or benefits that are subject to the restrictions contained in Division 2 of Part 2D.2. Section $200 A B(1)$ of the Australian Corporations Act 2001 defines "benefit" for the purposes of Division 2 of Part 2D.2 to include a payment or other valuable consideration, any kind of real or personal property, any legal or equitable estate or interest in real or personal property, any legal or equitable right and a thing specified in regulations made for the purposes of this section. ${ }^{69}$ In terms of paragraph 2D.2.02(1) of the Corporations Regulations 2001 payments considered to be benefits include inter alia:

- Any kind of pension other than a pension paid from a superannuation fund or a superannuation annuity.

- Amounts paid as a voluntary out-of-court settlement in a matter relating to the termination of employment.

- Payments made as part of restrictive covenants, restraint of trade clauses or non-compete clauses the value of which, when added to the value of any other payments made or payable in connection with the person's

personnel for the consolidated entity (if consolidated financial statements are required) or for each member of the key management personnel for the company (if consolidated financial statements are not required.

67 S 200AA(3)(a) and (b).

68 S 9 of the Australian Corporations Act 2001 provides that the term "key-management personnel" has the same meaning as in the accounting standards. In terms of Accounting Standard AASB 124.9 "key-management personnel" refers to those persons having authority and responsibility for planning, directing and controlling the activities of the entity, directly or indirectly, including any director (whether executive or otherwise) of that entity.

69 S $200 \mathrm{AB}(1)(\mathrm{a})-(\mathrm{e})$. 
retirement, exceed the payment limit set by section $200 \mathrm{G}$ of the Australian Corporations Act 2001 (i.e. the retiree's annual base salary). ${ }^{70}$

Section $200 A(1)(a)$ provides that a benefit is given in connection with a person's retirement from an office or position if it is given by way of compensation for (or otherwise in connection with) the loss by the person of the office or position, or in connection with the person's retirement from the office or position. Section $200 \mathrm{~A}(1)$ (b) further specifies that giving a benefit includes making the payment where the benefit is a payment, and transferring the interest where the benefit is an interest in property. Giving a benefit occurs when the person giving the benefit is obliged to do so under a contract. $^{71}$

In terms of section $200 \mathrm{~A}(1 \mathrm{~A})$ a benefit is given in connection with a person's retirement from an office or position if it is given in the circumstances specified in the regulations. These are circumstances in which:

- the benefit is the automatic vesting of share-based payments for a person on or as a result of retirement from office or position;

- the benefit is the accelerated vesting of share-based payments for a person on or as a result of retirement from office or position, and

- the benefit is a payment made to a person in lieu of the giving of notice of termination. $^{72}$

Section $200 A(1)(e)$ defines "retirement from an office or position" widely to include loss of the office or position, resignation from the office or position, as well as death of persons at a time when they hold the office or position.

The effect of the broad definition of what constitutes a retirement benefit is to cover all the types of compensation that are awarded to company directors and senior executives upon termination of their service contracts or retirement from office. The detailed definition of what constitutes a retirement benefit is aimed at clarifying the types of payments that are subject to the restrictions on the payment of retirement benefits, and also to clarify the types of payments that are not.

\section{Shareholder approval of retirement benefits}

Section $200 \mathrm{~B}(1)$ of the Australian Corporations Act 2001 prohibits a company, an associate of the company and a prescribed superannuation

\footnotetext{
70 However, in terms of section $200 \mathrm{AB}(2)$ of the Australian Corporations Act 2001, read with paragraph 2D.2.02(1) of the Corporations Regulations 2001, a benefit does not include the following, inter alia: deferred bonuses; payments from defined benefits superannuation schemes; genuine superannuation contributions paid by an employer or employee; genuine accrued benefits payable under a law (otherwise than because of breach of contract or breach of trust); such as payment of annual leave, long service or sick leave; payments under a requirement imposed by a law of another country; a reasonable payment made in accordance with the company's policy that applies to all employees, as a result of a genuine redundancy, and having regard to the length of a person's service; and payments from prescribed superannuation funds due to death or incapacity.

71 S 200A(1)(c).

72 Par 2D.2.03 of the Corporations Regulations 2001.
} 
fund in relation to the company ${ }^{73}$ from giving a person a benefit (as defined in paragraph 51 above) in connection with a person's (the retiree's) retirement from office or position of employment in a company or a related body corporate if the office or position is a managerial or executive office, unless the giving of the benefit is approved by shareholders. ${ }^{74}$ This requirement also applies where the retiree has held a managerial or executive office in the company, or a related body corporate at any time during the last 3 years prior to his or her retirement. ${ }^{75}$

Notably, the recipient of the benefit needs not be the retiree. This would prevent circumvention of the restrictions on retirement benefits through the giving of benefits to related parties. Furthermore, section 200A(2) provides that, if person A gives benefit A for the purpose, or for purposes including the purpose, of enabling or assisting someone to give a person a benefit in connection with the retirement of person $B$ from an office or position, then person $A$ is taken to give benefit $A$ in connection with person $B$ 's retirement from that office or position. This prevents the circumvention of the restrictions on termination benefits through the giving of related benefits.

Similarly, section $200 \mathrm{C}$ prohibits the giving of a benefit to a person who holds or has held a managerial or executive office in connection with the transfer of the whole or any part of the undertaking, or property of the company unless the giving of the benefit is approved by shareholders. ${ }^{76}$ Again, the recipient of the benefit need not be the person who holds or has held a managerial or executive office in a company or a related body corporate. This is so because section $200 \mathrm{C}$ further prohibits the giving of the benefit to such person's spouse or relative (or the spouse of the relative) or associate (or the spouse of the associate) without shareholder approval.

Although retirement benefits are generally subject to shareholder approval in terms of section $200 \mathrm{~B}(1)$, the Australian Corporations Act 2001 provides for specific circumstances where the requirement for shareholder approval does not apply. ${ }^{77}$ Notably, section $200 \mathrm{~F}(2)$ provides that shareholder approval is not required if the retirement benefit is a genuine payment of

73 "Superannuation fund" is defined in s $200 \mathrm{~B}(1 \mathrm{~A})(4)$ of the Australian Corporations Act 2001 to mean a provident, benefit, superannuation or retirement fund. Such superannuation fund is considered to be a prescribed superannuation fund in relation to a company if the company or an associate of the company gives a benefit to the superannuation fund for the sole purpose of enabling or assisting the superannuation fund to give to a person a benefit in connection with the retiree's retirement from an office or position in the company or a related body corporate. A superannuation fund is also considered to be a prescribed superannuation fund in relation to a company if the former gives a benefit to another superannuation fund solely for the purpose of enabling or assisting the other superannuation fund to give to a person a benefit in connection with the retiree's retirement from an office or position in a company or a related body corporate. See s $200 B(1 A)(1)$ and (2).

74 In terms of $s 200 E(1 B)$ the resolution approving the giving of the benefit must be passed at a general meeting of the company. If the company is a subsidiary of a listed domestic corporation, the resolution must be passed at a general meeting of the listed corporation. If the company is a subsidiary of an unlisted domestic corporation (which is not itself a subsidiary of a domestic corporation), the resolution must be passed at a general meeting of the holding company.

$75 \mathrm{~S} 200 \mathrm{~B}(1)(\mathrm{b})$.

76 S 200E which provides for approval by shareholders.

$77 \mathrm{~S} 200 \mathrm{~F}, 200 \mathrm{G}$ and $200 \mathrm{H}$. 
damages for breach of contract, or is given to the person under a contract with the company as the consideration for agreeing to hold the office or position, provided that the value of the benefit, when added to the value of all other benefits already given in connection with the person's retirement, does not exceed the retiree's annual base salary. In the same vein, section $200 \mathrm{G}$ (1) provides that shareholder approval is not required if the retirement benefit is for past services rendered to the company or a related body corporate, and the value of the benefit, when added to the value of any other benefits already given, does not exceed the retiree's annual base salary. Thus only the retirement benefits in excess of the retiree's annual base salary would be subject to shareholder approval. ${ }^{78}$

The prescribed threshold for shareholder approval of retirement benefits has been criticized on the basis that the one-year base-salary threshold is too low and will likely be circumvented by companies through increasing their directors' and executives' base salaries. ${ }^{79}$ It has thus been contended that the shareholder-approval threshold be set at two years total remuneration instead of one-year base pay. ${ }^{80}$ Nevertheless, it is submitted that the requirement of shareholder approval supports transparency and the accountability of company boards in determining retirement benefits. Shareholders are able to reject retirement benefits, proposed by company boards, if they are considered as being excessive or amounting to rewards for failure.

For there to be shareholder approval for the giving of the retirement benefit, section $200 \mathrm{E}(2)$ requires that the details of the benefit must be disclosed in, or accompany, the notice of the general meeting that is to consider the resolution. In the event that the proposed benefit is a payment, the amount of the payment must be disclosed. If the amount cannot be ascertained at the time of the disclosure, then the manner in which that amount is to be calculated and any circumstances that will, or is likely to, affect the calculation of that amount, must be set out ${ }^{81}$ In any other event, the money value of the proposed benefit must be disclosed. If the value of the benefit cannot be ascertained at the time of the disclosure, then the manner in which it is to be calculated and any circumstances that will, or is

78 In an effort to increase certainty, the term "base salary" is defined in regulation 2D.2.01 of the Corporations Regulations 2001 to mean (1) the specified components of a short-term employee benefit that are not dependent on the satisfaction of a performance condition and are paid during the relevant period; (2) a superannuation contribution that is not dependent on the satisfaction of a performance condition and is paid during the relevant period; (3) a specified share-based payment that is not dependent on the satisfaction of a performance condition and that is paid during the relevant period; and (4) a liability or prospective liability to pay tax in respect of a fringe-benefit taxable amount under the Fringe Benefit Tax Assessment Act 1986 or the Fringe Benefits Tax Act 1986, that relates to the provision of a matter specified in item (1), (2) or (3) above.

79 Australian Institute of Corporate Directors "Submission by The Australian Institute of Company Directors to Treasury in response to the Exposure Draft: Corporations Amendment (Improving Accountability on Termination Payments) Bill 2009" May 2009 http://www.pc.gov.au/inquiries/completed/executive-remuneration/submissions/sub059-part 3.pdf (accessed 2016-01-28) 8-9.

80 Australian Institute of Corporate Directors http://www.pc.gov.au/inquiries/completed/ executive-remuneration/submissions/sub059-part3.pdf 13.

$81 \mathrm{~S} 200 \mathrm{E}(2)(\mathrm{a})(\mathrm{i})$ and (i) of the Australian Corporations Act 2001. 
likely to, affect the calculation of that value, must be disclosed. ${ }^{82}$ These requirements further enhance transparency and would enable shareholders to cast their votes in an informed manner.

Notably, section $200 E$ expressly states that shareholder approval does not relieve a director from any duty to the company in connection with the giving of the benefit, whether statutory ${ }^{83}$ or otherwise, and whether of a fiduciary nature or not. It is, therefore possible for disgruntled minority members to use the statutory derivative action to recover inappropriate termination payments on behalf of the company. ${ }^{84}$

\section{Consequences of contravention of the provisions}

The contravention of the provisions of the Australian Corporations Act 2001, dealing with retirement benefits, may lead to severe criminal or civil penalties for both individuals and corporate entities. The giving of benefit in contravention of section 200B or 200C (i.e. without shareholder approval) constitutes an offence of strict liability, resulting in criminal penalties. ${ }^{85}$ In the case of section $200 \mathrm{~B}$, the offence is committed by the a company, an associate of the company or a prescribed superannuation fund in relation to the company that gives the retirement benefit in connection with the retiree's, or someone else's retirement without shareholder approval. In the case of section 200C, the offence is committed by any person who gives a benefit to a person dealing with the transfer of the whole or any part of the undertaking or property of the company. Furthermore, receiving a benefit if the giving of the benefit contravenes section $200 \mathrm{~B}$ or $200 \mathrm{C}$, constitutes an offence of strict liability.

Section 200J provides for civil consequences where an entity contravenes section $200 \mathrm{~B}$ by giving a retirement benefit to a person. In terms of section $200 \mathrm{~J}(1)$, read with subsection (2), the whole of the amount of the benefit or of the money value of the benefit (where the benefit is not a payment) is deemed to be received by the recipient on trust, and must be repaid by the recipient to the giver. In addition, the whole of the amount or value of the benefit remains a debt due to the giver, and may be recovered in a court of competent jurisdiction. ${ }^{87}$

82 S $200 E(2)(b)(i)$ and (i). These requirements are in addition to any other law that requires disclosure to be made with respect to giving or receiving a benefit.

83 See s section 180, 181, 182, 183 and 184 of the Australian Corporations Act 2001.

84 See Cummings Engineering Holdings Pty Ltd ACN 001794743 [2014] NSW SC 250 in which the New South Wales Supreme Court, relying on $S 200 E(4)$ held that the directors were liable to compensate the company for the loss caused by awarding an improper termination payment on the basis that they acted in breach of the duty to act in good faith in the best interests of the company, the duty not to improperly use their position to gain an advantage for themselves or someone else, and the general fiduciary duties. 85 S $200 \mathrm{~B}(1 \mathrm{~A})$ and $200 \mathrm{C}(2)$ of the Australian Corporations Act 2001 . This offence may be
committed by a person who holds or has held a managerial or executive office in a company or related body corporate (person $A$ ), or the spouse of person $A$, or a relative of person $A$ or of the spouse of such a person, or an associate of person A or the spouse of an associate of such a person.

86 S 200D.

$87 \mathrm{~S} 200 \mathrm{~J}(1 \mathrm{~A})$. 
Regarding the giving and receiving of retirement benefits in contravention of sections $200 \mathrm{~B}$ and $200 \mathrm{C}$ as offences of strict liability, seems quite punitive. It is also worth noting that section $200 \mathrm{~J}$ requires that the whole of the amount of a payment or of the money value of the benefit must be held on trust by the recipient, and repaid to the giver "even though giving the benefit would not have contravened section 200B if that amount or value of the benefit had been less" ${ }^{88}$ This provision also appears very punitive. It is, therefore, submitted that the punitive criminal and civil penalties would exert strong pressure on companies to adhere to the provisions on retirement benefits. They reflect the strong position that the Australian lawmakers have adopted in order to deter excessive retirement benefits, and to ensure meaningful shareholder participation in the determination of these payments. ${ }^{89}$ The requirement that the recipient of a retirement benefit that has been given without shareholder approval must hold such benefit on trust, is aimed at increasing the accountability of the recipient, especially where the recipient has failed to repay it to the giver immediately. ${ }^{90}$

\section{Additional controls on retirement benefits in regard to listed companies and the "two-strikes" rule.}

Section 300(1)(e)(vii) of the Australian Corporations Act 2001 requires listed companies to disclose information about the termination payments in the directors' and senior executives' contracts annually in the directors' remuneration report. Such information must include, in the case of a person who is employed by the company under a contract, the duration of the contract, the periods of notice required to terminate the contract and the termination payments provided for under the contract. This information must be given for each person who is a member of the key-management personnel for the company or for the consolidated entity (if consolidated financial statements are required). ${ }^{91}$

However, the actual contracts would not be subject to examination by the shareholders. This is so because section 300A(1)(e)(vii) of the Australian Corporations Act 2001 does not go as far as the 2013 Regulations in the UK which require quoted companies to provide details of where the directors' contracts and letters of appointment are kept (in cases where these are not available for shareholder inspection at the company's registered office), which may include giving a link to a specific website in the event that the contracts are available on a website.

In terms of section $250 \mathrm{R}(2)$, read with subsection (3) of the Australian Corporations Act 2001, a resolution to adopt a directors' remuneration report must be put to a non-binding advisory vote of the shareholders at a listed company's AGM. ${ }^{92}$ Shareholders of listed companies who are unhappy with

\footnotetext{
$S 200 J(2)$.

89 The Parliament of the Commonwealth of Australia https://www.comlaw.gov.au/Details/ C2009B00146/Download 16.

90 Ibid.

91 S $300 \mathrm{~A}(1)(\mathrm{e})$, read with paragraph (c) of the Australian Corporations Act 2001.

92 In terms of $s 249 L(2)(a)$ the notice of the annual general meeting of a listed company must inform shareholders that a resolution for the approval of the directors' remuneration report will be put at the annual general meeting.
} 
the termination-payments arrangements in the directors' and executives' contracts are further empowered under the "two-strikes" rule to vote against the remuneration report, and to potentially require that all the directors resign and stand for re-election within 90 days. ${ }^{93}$ This would compel the board of directors to take shareholder concerns in relation to termination payments seriously.

\section{SOUTH AFRICA}

In South Africa legislative controls on directors' and prescribed officers' termination payments are contained in section 30(4) of the Companies Act ${ }^{95}$ and its related provisions. Although the King IV Report on Corporate Governance for South Africa 2016 contains important provisions regarding termination payments to directors and prescribed officers, these provisions are not binding. This part will examine the adequacy of the relevant provisions of the Companies Act. ${ }^{96}$

\section{Definition of "termination payment"}

Although section 30(4)(c) of the Companies $\mathrm{Act}^{97}$ requires disclosure in the company's annual financial statements of any compensation paid in respect of loss of office to current or past directors or prescribed officers, there is no definition of "compensation paid in respect of loss of office" in the Companies Act 71 of 2008. Notably, the broad definition of the term "remuneration" in section 30(6) (in the context of information disclosure in the annual financial statements) does not include "compensation paid in respect of loss of office". It is, therefore, not clear what "compensation paid in respect of loss of office" encompasses. This is in contrast to the UK Companies Act 2006 and the Australian Corporations Act 2001 which contain a separate and comprehensive definition of "payment for loss of office" and "retirement benefit", respectively. A clear definition of "a termination payment" or "compensation paid in respect of loss of office" is essential in view of the complex remuneration arrangements and packages

93 A $25 \%$ (or more) vote against the adoption of the remuneration report at the AGM (earlier AGM) is considered to be the first strike. If at the subsequent AGM (the later AGM) the adoption of the remuneration report is rejected by at least $25 \%$ of the votes (this is considered to be the second strike) a resolution (the spill resolution) must be put to vote that another shareholders' meeting (the spill meeting) be held within 90 days, and the company's directors would be required to resign and stand for re-election at the spill meeting. See s 250V(1) of the Australian Corporations Act 2001. See also Kovačević "Executive Remuneration Developments in Australia: Responses and Reactions" 201223 The Economic and Labour Relations Review 99 104; and Luiz "Executive Remuneration and Shareholder Voting" 201325 SA Merc LJ 267273 for a discussion of the "two strikes" rule.

94 See also s $300 \mathrm{~A}(1)(\mathrm{g})$ of the Corporations Act which provides that, if comments were made on the remuneration report that was considered at the company's most recent AGM, and when a resolution for the adoption of the remuneration report was voted against by at least $25 \%$ of the votes cast, the remuneration report for the next financial year must also include an explanation of the board's proposed action in response. If the board does not propose any action, the board's reasons for inaction must be included.

9571 of 2008 .

96 lbid

97 Ibid. 
in modern times. It should be clear which elements constitute "compensation paid in respect of loss of office" in order to provide companies and their stakeholders with certainty.

\section{Disclosure of termination payments}

In terms of section 30(4)(c) the annual financial statements of a company that are required in terms of the Companies $\mathrm{Act}^{98}$ to be audited, must disclose the amount of any compensation paid in respect of loss of office to current or past directors or individuals who hold or have held any prescribed office in the company. ${ }^{99}$ The "details of service contracts" of current directors and prescribed officers of the company must also be disclosed. ${ }^{100}$

Furthermore, section 30(5) requires the information to be disclosed under subsection (4) to show the amount of any "remuneration" or "benefits" paid to or receivable by persons in respect of -

“(a) services rendered as directors or prescribed officers of the company; or

(b) services rendered while being directors or prescribed officers of the company -

(i) as directors or prescribed officers of any other company within the same group of companies; or

(ii) otherwise in connection with the carrying on of the affairs of the company or any other company within the same group of companies."

The disclosure of the amount of compensation paid in respect of loss of office and the details of service contracts, is welcome. However, there are significant omissions in section $30(4)$ and its related provisions. First, section 30 (5) uses the terms "remuneration" and "benefits" and does not refer to "compensation paid in respect of loss of office". It is, therefore, not clear whether the disclosure requirements of section 30(5)(b) are applicable to compensation paid in respect of loss of office. It is not clear whether the amounts paid in respect of loss of office as director or prescribed officer of any other company within the same group of companies, must be disclosed. It is also not clear whether the amounts paid in respect of loss of any other office or employment in connection with the carrying on of the affairs of the company, or any other company within the same group of companies, must be disclosed. It is submitted that these amounts should be disclosed, as is the case under the UK Companies Act 2006 and the Australian Corporations Act 2001.

Secondly, the Companies Act ${ }^{101}$ does not require companies to provide a detailed disclosure of the various components of the total termination

98 71 of 2008.

99 S 30(2)(a) of 71 of 2008 provides that the annual financial statements of a public company must be audited. In the case of any other profit or non-profit company, the annual financial statements must be audited if so required by the regulations made in terms of $s 30(7)$, taking into account whether it is desirable in the public interest, having regard to the economic or social significance of the company, as indicated by any relevant factors, including its annual turnover, the size of its workforce, or the nature and extent of its activities. See $\mathrm{s} 30(2)(\mathrm{b})$ of 71 of 2008.

$100 \mathrm{~S} 30(4)(\mathrm{e})$ of 71 of 2008.

10171 of 2008. 
package, including an explanation of how each component has been calculated. It appears that merely disclosing the total amount of the termination package would be sufficient to satisfy the requirements of section $30(4)(c)$. It is submitted that the various components making up the total termination package should be disclosed and explained separately in order to achieve greater transparency.

Thirdly, while the requirement for disclosure of the "details of service contracts" of current directors and prescribed officers in section 30(4)(e) is welcome, this provision does not specify which "details of service contracts" must be disclosed. There is thus no guarantee that detailed information on termination payments will be disclosed in the company's annual financial statements. It is submitted, in this regard, that the Companies Act ${ }^{102}$ should further require companies to provide shareholders with access to the directors' and prescribed officers' service contracts and letters of appointment. This would create greater transparency in relation to compensation for loss of office arrangements which are embedded in such contracts and letters of appointment. In the UK, as discussed above, if the directors' service contracts are not kept available for inspection at the company's registered office, the company must provide details of where the contracts are kept, or a link to a website on which the contracts are available. Providing company shareholders access to the entire contractual arrangements enables them to scrutinize the specific terms of the contracts.

Fourthly, the remuneration information disclosed in the annual financial statements in accordance with section 30(4) is not subject to shareholder approval. Therefore, even if detailed information on termination payments is disclosed under section 30(4), there is nothing to limit the discretion of company boards to award excessive termination packages to directors and executives despite poor performance. In contrast, an annual directors' remuneration report is subject to an advisory shareholder vote under both the UK Companies Act 2006 and the Australian Corporations Act 2001. Even though the vote is not binding on companies, a negative vote has serious consequences for the company and its directors under both statutes, as discussed above. This gives teeth to the advisory vote and would compel companies in these two jurisdictions to take shareholder concerns on, amongst other matters, the aspects related to termination payments, more seriously.

\section{Disclosure of the policy on termination payments}

The Companies $\mathrm{Act}^{103}$ does not require companies to formulate and disclose their policies on termination payments. ${ }^{104}$ This is in contrast to the 2013 Regulations in the UK which, as discussed above, requires the directors' remuneration policy to set out the company's approach on the determination of payments for loss of office, including an indication of how each component of the payment will be calculated. It is submitted that the

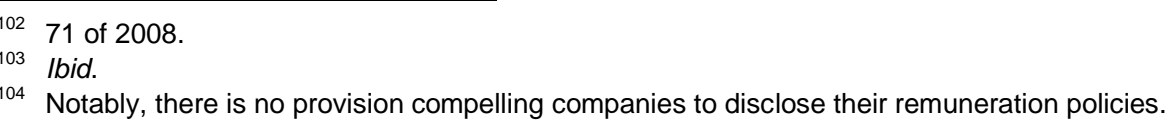


Companies $\mathrm{Act}^{105}$ should contain a provision requiring companies to have in place clearly defined policies governing termination payments. In addition, the companies should be required to disclose such policies publicly.

\section{Shareholder control over termination payments}

The extent of the shareholder control over termination payments under the Companies Act ${ }^{106}$ is severely limited. The presentation of the audited annual financial statements to the shareholders' meeting, as required by section $30(3)(d)$, affords shareholders an opportunity to engage with the board of directors on directors' and prescribed officers' termination payments that are disclosed in the statements. ${ }^{107}$ This form of engagement may, however, be foiled by the inadequate disclosure requirements on the termination payments discussed above.

Furthermore, the timing of the disclosure of termination payments under the Companies Act ${ }^{108}$ is flawed. Section 30(4)(e) requires disclosure of the amount of any compensation in respect of loss of office after the payment has already been made. The disclosure may take place several months following the making of the payment. Thus shareholder engagement on the actual termination payments awarded to departing directors and prescribed officers may add little value since it will occur after the event. It is, therefore, submitted that companies should be required to disclose the termination arrangements and the actual payments prior to payment, as is the case under the UK Companies Act 2006 and the Australian Corporations Act 2001.

A further drawback of the Companies $\mathrm{Act}^{109}$ is that it does not provide for shareholder approval of compensation in respect of loss of office. Although section 66(8) and (9) provides that the remuneration of directors for their service as such must be approved by a special resolution of the shareholders in advance, there is no definition in the Companies Act ${ }^{110}$ in regard to the meaning of "remuneration" in the context of section 66(8) and (9). The only definition of "remuneration" is contained in section $30(6)$, which defines "remuneration" broadly for purposes of disclosure in the annual financial statements. However, the broad definition of remuneration in section 30(6), as discussed above, does not include compensation in respect of loss of office.

By contrast, the UK Companies Act 2006 and the Corporations Act 2001 specifically require termination payments to be approved by the company's shareholders in advance. In the absence of an equivalent requirement in South Africa there is nothing to limit the discretion of the boards of directors

10571 of 2008.

106 Ibid.

$107 \mathrm{~S} 30(3)(d)$ of 71 of 2008 provides that the annual financial statements of a company must be presented to the first shareholders meeting after the statements have been approved by the board. See also s 61(8)(a)(ii) of 71 of 2008 which requires that a public company's annual general meeting must provide for the presentation of audited financial statements for the immediately preceding financial year.

10871 of 2008.

109 Ibid.

110 lbid. 
to pay exorbitant, and often controversial, termination packages to former directors and executives despite poor performance.

Notably, the Companies Act ${ }^{111}$ has no equivalent provision to section 227(1)(a) of the Companies Act 61 of $1973 .{ }^{112}$ This provision prohibited the company from making any payment, or granting any benefit or advantage to "any director or past director of the company or of its subsidiary company or holding company or of any subsidiary of its holding company by way of compensation for loss of office, or as consideration for or in connection with his retirement from office", unless full particulars with respect to the proposed payment, benefit or advantage have been disclosed to the shareholders and the making of the payment, or the grant of the benefit or advantage has been approved by special resolution. ${ }^{113}$ This presumably gave shareholders some form of control over termination packages payable to directors for loss of, or retirement from office. ${ }^{114}$

\section{Consequences of contravention of the provisions}

Failure to disclose the amount of any compensation paid in respect of loss of office or details of directors' service contracts, as required by section $30(4)$ (c) and (e) of the Companies Act, ${ }^{115}$ may lead to civil consequences, particularly where the non-disclosure would render the financial statements false or misleading in a material respect. This is so because section $77(3)$ (d)(i) provides that a director of a company is liable for any loss, damages or costs sustained by the company as a direct or indirect consequence of the director's signing, consenting to or authorizing the publication of any financial statements that were false or misleading in a material respect, despite having known that the statement was false, misleading or untrue. A director may be held jointly and severally liable with any other person who is or may be held liable for the same act. ${ }^{116}$ It is also important to note, in this context, that the Companies Act also provides for general civil liability for contravention of its provisions. ${ }^{117}$ This general

11171 of 2008.

112 This provision dealt with payments to directors for loss of office or in connection with arrangements and take-over schemes.

$113 \mathrm{~S} 227(1)(\mathrm{a})$ of 61 of 1973.

114 In Peens and Swart v MKTV Beleggings Beherend BK [2003] 3 All SA 426 (T), the court had to consider whether the payment of resignation packages to Peens and Swart, who were employed by the company as Managing Director and Product Development Director respectively and who also served as directors of the company, was regulated by section 227(1) of the Companies Act 61 of 1973 which required inter alia shareholder approval of the payments. The court held that that the termination packages were not regulated by section 227(1) of the Companies Act 61 of 1973 since they were made as a result of the termination of the two men's service relationships in their capacities as managing director and product development director of the company, respectively, and not as directors. Professor Luiz has criticized the narrow approach adopted by the court in that case on the ground that it clearly limited the extent to which shareholders could exert any influence over the payment of executive-termination packages. See Luiz "Payments to Directors as Compensation for Loss of Office" 200517 SA Merc LJ 115120.

11571 of 2008.

$116 \mathrm{~S} 77(6)$ of 71 of 2008

117 For instance, s 20(6)(a) of 71 of 2008 affords each shareholder of a company a claim for damages against any person who intentionally, fraudulently or due to gross negligence, causes the company to do anything inconsistent with the Act. Further, any person who 
provision serves as a remedy to curb or deter contravention of the Companies Act.

As discussed above, the UK Companies Act 2006 provides for criminal penalties where the company has failed to put the directors' remuneration report to shareholder approval. The Australian Corporations Act 2001 provides for criminal penalties where termination payments are made without shareholder approval. In addition, both the UK Companies Act 2006 and the Australian Corporations Act 2001 provide for civil consequences where a termination payment is made without the requisite shareholder approval. This is not the case in South Africa under the Companies Act, ${ }^{118}$ which does not require termination payments to be approved by a resolution of the shareholders.

\section{RECOMMENDATIONS FOR SOUTH AFRICA}

The Companies Act ${ }^{119}$ is lagging behind the UK Companies Act 2006 and the Australian Corporations Act 2001 in regard to the regulation of directors' and executives' termination payments. It is submitted that the legislative techniques developed in the UK and Australia should be considered and, with the necessary adaptations, introduced to strengthen the Companies Act. It is, therefore, suggested that the following amendments should be made to the Companies Act in order to strengthen transparency, accountability and certainty in the area of termination payments, as well as to align the Companies Act with the legislative trends in these leading jurisdictions:

- The Companies Act should provide an appropriate definition of "compensation in respect of loss of office" in order to clarify the kinds of payments and benefits that will qualify as "compensation in respect of loss of office" and which would, therefore, fall within the ambit of the provisions on termination payments. Such definition should include cash payments and other benefits to present or past directors or prescribed officers as compensation for loss of office as director or prescribed officer, as well as for loss of any other office, or employment in connection with the management of the affairs of the company or its subsidiary. The ambit of the provisions should also cover a payment to a person connected with a director (or prescribed officer), as well as a payment to any person at the direction of, or for the benefit of, a director (or prescribed officer) or a person connected with him/her.

- The Companies Act should require shareholder approval for payments for loss of office, including payments for loss of office made in connection with transfer of the undertaking, property or shares of the company as is required in the UK and Australia. In the case of a subsidiary making a payment for loss of office to a director or prescribed officer of its holding company, approval by a resolution of the shareholders of each of the companies should be required. Where the payment is in connection with

contravenes any provision of the Act is liable to any other person for any loss or damage suffered by that person as a result of the contravention in terms of $s 218(2)$ of 71 of 2008 .

11871 of 2008.

119 lbid. 
the transfer of the undertaking or property of a subsidiary of the company, the payment must be approved by a resolution of the shareholders of each of the companies.

- Before a resolution approving a payment may be passed by the shareholders, the size and the breakdown of the termination payments should be disclosed and clearly explained to the shareholders.

- The above requirements should apply to every company which is registered in South Africa, save for a company that is a wholly-owned subsidiary of another company.

- The requirement of shareholder approval should, however, not relieve the directors from their duties to the company in connection with the making of the payment, as is the case in Australia. This would serve as a protection to the minority shareholders.

- The Companies Act should require companies that are presently required to comply with remuneration-disclosure requirements of section 30 (4) to disclose termination-payments arrangements in their remuneration policies which should be subject to formal shareholder approval. Companies should be required to disclose sufficient information on the mechanisms for calculating termination payments. There should be disclosure of the policy that determines the company's approach to all termination payments.

- Section 30(4) should further be amended to provide shareholders access to the directors and prescribed officers' service contracts and letters of appointment.

- Section 30(4) should also be amended to require companies to disclose, in addition to the amount of any compensation paid in respect of loss for loss of office, a detailed breakdown of each component comprised in that payment and the value of each component, as well as an explanation of how each component has been calculated.

- The remuneration information disclosed in terms of section 30(4) should be subject to formal shareholder approval as is the case in the UK and Australia.

- In order to strengthen compliance, the Companies Act should provide for direct and harsher consequences for both companies and individuals that do not comply with the provisions on termination payments.

- The Companies Act should require a termination payment that has been made in contravention of its provisions to be repaid by the recipient to the giver immediately. In addition, the Companies Act should provide that a termination payment that has been made in contravention of its provisions, must be held by the recipient on trust for the company or the person having made the payment.

\section{CONCLUSION}

The practice of awarding termination packages to departing company directors and senior executives has been a subject of increasing public and shareholder scrutiny in most jurisdictions due to the nature and the sheer 
size of golden handshakes, as well as the serious corporate governance challenges in the determination of these payments. There is a need to have in place an appropriate framework for the regulation of termination payments in order to promote transparency and accountability.

The article has evaluated the legislative controls on termination payments in South Africa under the Companies Act ${ }^{120}$ in light of the relevant provisions of the UK Companies Act 2006 and the Australian Corporations Act 2001. It has paid particular focus on the definitions of what constitutes a termination payment, shareholder control over termination payments, disclosure of termination payments and the penalties for contravention of the provisions on termination payments. It is submitted that the Companies Act ${ }^{121}$ is lagging behind the UK Companies Act 2006 and the Australian Corporations Act 2001 in these aspects.

Although section 30(4) of the Companies Act ${ }^{122}$ requires disclosure in the company's annual financial statements of any compensation paid in respect of loss of office to current or past directors or prescribed officers, there are significant omissions in this section and its related provisions. Moreover, the remuneration report disclosed in the annual financial statements in accordance with section 30(4), is not subject to shareholder approval. The Companies Act ${ }^{123}$ does not provide for shareholder approval of payments for loss of office.

It is submitted that the provisions of the Companies Act ${ }^{124}$ relating to directors' and executives' termination payments are inadequate in promoting transparency, accountability and certainty. It is, therefore, submitted that the legislative controls on termination payments in the UK Companies Act 2006 and the Australian Corporations Act 2001 should be considered and, with the necessary adaptations, introduced in the Companies Act ${ }^{125}$ in order to address the corporate-governance concerns on termination payments, whilst providing companies with certainty. This would be in line with section $7(b)$ (iii) which lists encouraging transparency and high standards of corporate governance as purposes of the Companies Act. ${ }^{126}$

\footnotetext{
12071 of 2008.

121 lbid.

122 lbid.

123 Ibid.

124 Ibid.

125 Ibid.

126 Ibid.
} 